\title{
Recent Developments in Hong Kong Bankruptcy Law Reform*
}

\author{
Charles D Booth**
}

Current Hong Kong insolvency law, primarily the Bankruptcy Ordinance ${ }^{1}$ and company winding up legislation, ${ }^{2}$ is based on English legislation that harks back to the late nineteenth century. Now, for the first time in almost a century, a substantial overhaul of Hong Kong insolvency law is under way. On 14 September 1990, at the request of the Chief Justice and the Attorney General, the Law Reform Commission of Hong Kong (the "Law Reform Commission") formed the Insolvency Sub-Committee to review and propose reforms to extant insolvency law legislation. The Insolvency Sub-Committee, under the Chairmanship of His Honour Judge E L G Tyler, commenced work on 2 November 1990. Within the next year the Insolvency Sub-Committee intends to issue two interim reports.

The first interim report will propose various procedural and technical amendments to current bankruptcy legislation. The second will deal with corporate reorganizations and will likely include a discussion of Administration Orders in the United Kingdom ${ }^{3}$ and Chapter 11 in the USA. ${ }^{4}$ It is understood that by March 1993 the Insolvency SubCommittee will complete its draft of the first interim report on the

* Copyright (C) 1992 by Charles D Booth. All rights reserved. This article is a revised version of a paper of the same name that I delivered to Committee $J$ Insolvency and Creditors' Rights at the International Bar Association Section on Business Law Conference, Hong Kong, 3 October 1991 .

** Lecturer, Faculty of Law, University of Hong Kong. BA, Yale University, 1981; JD, Harvard Law School, 1984.

1 Cap 6, Laws of Hong Kong 1992 (the "Bankruptcy Ordinance").

2 Which is found in the Companies Ordinance, cap 32, Laws of Hong Kong 1992 (the "Companies Ordinance").

3 Part II, ss 8-27, UK Insolvency Act 1986 (the "UK Insolvency Act 1986").

411 USCA ss 1101-1174 (West 1992), Chapter 11, US Bankruptcy Code, Bankruptcy Reform Act of 1978, Pub L No 95598,92 Stat 2549 , as further amended. 
amendments that it proposes to be made to current bankruptcy law and will then circulate these recommendations for comments by interested professional bodies and others for comments. After comments have been received, the Insolvency Sub-Committee will submit the final draft of its first interim report to the Law Reform Commission, most likely by mid 1993. The Law Reform Commission, in turn, will then publish the final recommendations for the reform of the bankruptcy legislation. It is anticipated that these recommendations on bankruptcy legislation will be enacted into law by 1994. Meanwhile, the second interim report on corporate reorganizations should likely be issued in late 1993. After issuing the second interim report, the Insolvency Sub-Committee will then review the rest of insolvency law. This is a mammoth task, and the report by the Insolvency Sub-Committee to the Law Reform Commission on this broad topic is unlikely to be made before the end of 1994, at the earliest.

This article does not offer a complete analysis of the likely insolvency reforms. Rather, it (i) discusses selected recommendations regarding bankruptcy that it is understood the Insolvency Sub-Committee will make in the first interim report; and (ii) notes some of the trends that appear to be emerging during the reform process.

Before making its recommendations, the Insolvency Sub-Committee first prepares working papers that compare current Hong Kong bankruptcy law with extant law in other jurisdictions including England and Wales, Scotland, Singapore, New Zealand, and Australia. (For comparative purposes, the related legislation in the United States would also have been helpful.) The Insolvency Sub-Committee has also looked, and will continue to look, at the recent reform movements in other Commonwealth jurisdictions, and thus relies heavily on the recommendations of the Report of the Review Committee on Insolvency Law and Practice in the United Kingdom (the "Cork Report"), many of which were incorporated into the UK Insolvency Acts 1985 and 1986, as well as on the recommendations of the Australian Law Reform Commission (the "Harmer Report"), ${ }^{6}$ some of which are in the process of being incorporated into Australian law.

It should be kept in mind that although Hong Kong often incorporates UK statutory provisions wholesale into Hong Kong law, such an ap-

5 Insolvency Law and Practice; Report of the Review Committee [United Kingdom, Cmnd 8558, June 1982], under the Chairmanship of Sir Kenneth Cork, GBE (the "Cork Report").
6 The Law Reform Commission of Australia: General Insolvency Inquiny, Report No 45 [Australia, September 1988], under the Chairmanship of Mr R W Harmer, BA LLB (Syd) (the "Harmer Report"). 
proach is not likely to be successful in the context of insolvency law. 'This is due to the existence of several special Hong Kong factors, many of which lead to a relatively small number of both bankruptcies and company liquidations. ${ }^{8}$ These special Hong Kong factors include the following: the nature of the typical Chinese firm, in which management and ownership functions are generally in the hands of the same individuals; the fact that until recently there was a small venture capital market in Hong Kong and companies grew slowly; the enforcement of the payment of debts through harsh legal methods (including the issuance of prohibition orders ${ }^{9}$ and the execution and enforcement of judgment for money by imprisonment $)^{10}$ and, at times, even harsher extra-legal methods (including the use of organized crime gangs called triads); ${ }^{11}$ the escalating number of fraud cases and instances of debtors and company directors absconding from Hong Kong in the run-up to $1997 ;{ }^{12}$ and the perception in the local business community that stigma attaches to those who are made bankrupt, or whose companies are "wound up". Also, in contrast to the United Kingdom, Hong Kong lacks an insolvency practi-

7 Tyler, "Company and Security Law", chapter 7 in Sihombing (ed), Annual Survey of the Law 1990-1991 (Hong Kong Law Journal Ltd, 1992) 153.

8 Tyler, ibid at 153. The factors noted in the text expand on the factors discussed in Tyler, "Current Issues in Insolvency", in C. Hague (ed) Commercial Law (Hong Kong Law Journal Ltd, 1991) 20-22.

As for the comparatively small number of bankruptcies and company liquidations in Hong Kong, in 1988-89 there were 194 bankruptcies and 151 compulsory liquidations; in 1989-90 there were 178 bankruptcies and 187 compulsory liquidations; in 1990-91 there were 226 bankruptcies and 306 compulsory liquidations; and in 1991-92 there were 294 bankruptcies and 355 compulsory liquidations. Annual Departmental Report of the Hong Kong Registrar General, 1991-92, Table XVIII. The number of bankruptcies and compulsory liquidations in 1991-92 were the second highest in the past decade, only 24 short of the 673 bankruptcies and compulsory liquidations reported in 1986-87. lbid.

The corporate failure rate in Hong Kong has also been lower than the corporate failure rate for the United Kingdom. For instance the annual corporate failure rate in Hong Kong was as follows: 1986
$0.78 \% ; 19871.20 \% ; 19880.94 \%$. This failure rate in the United Kingdom during the same period was $2.27 \%$. Tyler, "Current Issues in Insolvency Law", ibid, at 20.

9 The issuance of a prohibition order by the District Court under section 52E of the District Court Ordinance, cap 336, Laws of Hong Kong (1991) was upheld by the Hong Kong court of Appeal in Tam Hingyee v Wu Tai-Wai, Court of Appeal Civ App No 118 of 1991, 28 November 1991, as not violating the Hong Kong Bill of Rights. See discussion of this case in the Bill of Rights Bulletin (A Byrnes \& J M M Chan (eds)), Vol l(2), December 1991, at 13-14.

10 See Order 49B, The Rules of the Supreme Court of Hong Kong (1992).

11 See the newspaper article, "Unacceptable face of business", South China Moming Post, Review Section, p 1, 2/2/91, which reported the views of a $\mathrm{Mr}$ Chan (an assumed name) who used the triads to collect a HK\$1,000,000 debt within one week. He stated, "The triads charge $30 \%$ but at least it means I get $70 \%$ more in return than if I put it in the hands of the police." Mr Chan also claimed, "The triads are 'professional' debt-collectors. I think these triads will get really busy in the run-up to 1997 as people are making a quick fortune and don't care who [sic] they hurt along the way." 
tioners' body, as well as an enforcement authority with the professional experience and funding resources of departments such as the Department of Trade and Industry in the United Kingdom.

It is understood that the Insolvency Sub-Committee has discussed the following topics and is likely to make the following proposals.

\section{Topic 1. Grounds for presenting a bankruptcy petition}

\section{Ukely recommendations of the Insolvency Sub-Committee}

- Acts of bankruptcy should be abolished.

- The provisions of section 267 and 268 of the UK Insolvency Act 1986 should be adopted to replace acts of bankruptcy.

- A provision should be added to the adopted section 268 of the UK Insolvency Act 1986 that a debtor is deemed to be unable to pay his debts if the debtor has departed or remained out of Hong Kong with the intention of defeating, delaying or obstructing the claim of his creditors.

- The grace period of three weeks given to a debtor to comply with the terms of a statutory demand should be capable of curtailment if there is a probability that the debtor's assets will be diminished during the grace period.

- In the event of a default by a debtor under the terms of a voluntary arrangement the supervisor of, or any person bound by, a voluntary arrangement may present a petition to the court for a bankruptcy order to be made against the debtor.

Topic 1 proposes what is perhaps the most far reaching recommendation - that the concept of acts of bankruptcy be abolished. This concept can be traced back to the early English statutes enacted in the Middle Ages. ${ }^{13}$ These early statutes, as well as current Hong Kong law, are pre-

12 In 1991-92, 14 bankrupts and 23 directors or officers of companies in liquidation were arrested for absconding or avoiding examination of their affairs under the Bankruptcy and Companies Ordinances. Annual Departmental Report of the Hong Kong Registrar General, 1991-92, para 116. The figures for previous years were as follows:

1990-91: 17 bankrupts and 8 directors or officers were arrested, Annual Departmental Report of the Hong Kong Regis- trar General, 1990-91, para 111. 1989-90: 19 bankrupts and 4 directors or officers were arrested, Annual Departmental Report of the Hong Kong Registrar General, 1989-90, para 151. 1988-89: 30 bankrupts and 8 directors or officers were arrested, Annual Departmental Report of the Hong Kong Registrar General, 1988-89, para 145.

13 See Act Against Such Persons As Do Make Bankrupt, 34 and 35 Henry VIII ch 4 (1542); 13 Eliz ch 7, III (1571). 
mised on the notion that before creditors are allowed to share in the collective remedies provided for by bankruptcy law, a debtor must first commit an "act of bankruptcy". Under this approach, certain types of conduct (generally, "badges of fraud") by the debtor, and not financial embarrassment, are necessary to trigger the statute. ${ }^{14}$ Section $3(1)$ of the Hong Kong Bankruptcy Ordinance (the "Bankruptcy Ordinance") specifies that a debtor commits an act of bankruptcy upon the occurrence of various actions committed by (and in one case, against) a debtor, including the following: making a conveyance or assignment of his property to a trustee or trustees for the benefit of his creditors generally; making a fraudulent conveyance, gift, delivery, or transfer of his property or of any part thereof; making a conveyance or transfer of his property or any part thereof, or creating any charge thereon, which would be void as a fraudulent preference if he were adjudged bankrupt; with intent to defeat or delay his creditors, departing out of Hong Kong, or being out of Hong Kong remaining out of Hong Kong, or departing from his dwelling-house or usual place of business, or otherwise absenting himself, or beginning to keep house, or removing his property or any part thereof beyond the jurisdiction of the court; having execution levied against him by seizure of his goods and the goods having been either sold or held by the bailiff for 21 days; filing in the court a declaration of his inability to pay his debts or presenting a bankruptcy petition against himself; not complying with the requirements of a bankruptcy notice issued under section 4 of the Bankruptcy Ordinance within seven days after service of the notice, when the service is effected in Hong Kong; and giving notice to any of his creditors that he has suspended or that he is about to suspend payment of his debts. ${ }^{15}$ Many of these acts (such as "beginning to keep house") date from an earlier time, are no longer, or rarely, relied on by creditors when filing a bankruptcy petition in Hong Kong, and no longer serve a useful purpose. The Cork Report reached the same conclusion and stated that most of the acts of bankruptcy "are obsolete or obsolescent; their abolition will greatly simplify and modernise the law of bankruptcy." 16 It is understood that the Insolvency Sub-Committee relied heavily on the Cork Report's recommendation that the concept of acts of bankruptcy be abolished.

In recommending that the concept of acts of bankruptcy be abolished, the Insolvency Sub-Committee will likely be recommending that they be replaced by four grounds on which to base a bankruptcy petition: (i) a

14 Baird and Jackson, Cases, Problems, and Materials on Banknipicy, 2nd ed (1990) 27
15 Ss 3(1)(a)-(h), Bankruptcy Ordinance. 16 The Cork Report, para 529. 
debtor's failure to comply with a bankruptcy notice; (ii) a debtor's failure to satisfy an execution of a judgment debt; (iii) the absconding of a debtor from Hong Kong; and (iv) the default by a debtor under the terms of a voluntary arrangement. The first ground, a debtor's failure to comply with a bankruptcy notice, will almost certainly be the ground most frequently relied upon. (It is understood that the Insolvency SubCommittee noted the Harmer Report's finding that in 95\% of bankruptcy cases the creditors proved the non-compliance by the debtor with a bankruptcy notice ${ }^{17}$ and that the Insolvency Sub-Committee believes that this figure accurately reflects the situation in Hong Kong.) The Insolvency Sub-Committee's likely recommendation to abolish the concept of acts of bankruptcy and substitute grounds (i), (ii), and (iv) noted above, would change the principles underlying bankruptcy, so that bankruptcy would be based more on the financial difficulties of the debtor rather than on improper conduct by a debtor. This is an important policy change from current law. However, the Insolvency SubCommittee is unwilling to base the commencement of bankruptcy solely on financial difficulties of the debtor, because the sub-committee is understood to be concerned with the problems caused by debtors absconding from Hong Kong. For instance, in 1991-92, 14 bankrupts and 23 directors or officers of companies in liquidation were arrested for absconding or avoiding examination of their affairs under the Bankruptcy and Companies Ordinances. ${ }^{18}$ It is understood that the Insolvency SubCommittee is especially concerned that with the approach of 1997 (and the resulting increase in emigration from Hong Kong) there will continue to be instances of some debtors incurring substantial debts prior to their departure from Hong Kong that they have no intention of repaying. It is understood that for these reasons the sub-committee's recommendations will also likely include the third ground noted above. This ground appears to be a sensible inclusion, given the unique Hong Kong situation.

To incorporate the first and second grounds above, the Insolvency Sub-Committee will likely recommend adoption of sections 267 and 268 of the UK Insolvency Act 1986, the relevant subsections of which provide as follows:

Section $267(2) \ldots$. [A] creditor's petition may be presented to the court in respect of a debt or debts only if, at the time the petition is presented - 
(a) the amount of the debt, or the aggregate amount of the debts, is equal to or exceeds the bankruptcy level,

(b) the debt, or each of the debts, is for a liquidated sum payable to the petitioning creditor, or one or more of the petitioning creditors, either immediately or at some certain, future time, and is unsecured,

(c) the debt, or each of the debts, is a debt which the debtor appears either to be unable to pay or to have no reasonable prospect of being able to pay, and

(d) there is no outstanding application to set aside a statutory demand served (under section 268 below) i[n] respect of the debt or any of the debts.

Section 268(1) For the purposes of section 267(2)(c), the debtor appears to be unable to pay a debt if, but only if, the debt is payable immediately and either -

(a) the petitioning creditor to whom the debt is owed has served on the debtor a demand (known as "the statutory demand") in the prescribed form requiring him to pay the debt or to secure or compound for it to the satisfaction of the creditor, at least three weeks have elapsed since the demand was served and the demand has been neither complied with nor set aside in accordance with the rules, or

(b) execution or other process issued in respect of the debt on a judgment or order of any court in favour of the petitioning creditor, or one or more of the petitioning creditors to whom the debt is owed, has been returned unsatisfied in whole or in part.

(2) For the purposes of section 267(2)(c) the debtor appears to have no reasonable prospect of being able to pay a debt if, but only if, the debt is not immediately payable and -

(a) the petitioning creditor to whom it is owed has served on the debtor a demand (also known as "the statutory demand") in the prescribed form requiring him to establish to the satisfaction of the creditor that there is a reasonable prospect that the debtor will be able to pay the debt when it falls due,

(b) at least 3 weeks have elapsed since the demand was served, and

(c) the demand has been neither complied with nor set aside in accordance with the rules.

To incorporate the third ground regarding absconding debtors, the Insolvency Sub-Committee will likely recommend adoption of language along the following lines, which is based on paragraph 365 of the Harmer Report: 
A debtor is deemed to be unable to pay his debts if the debtor has departed or remained out of Hong Kong with the intention of defeating, delaying or obstructing the claim of his creditors. ${ }^{19}$

The incorporation of the fourth ground, regarding an event of default by a debtor under the terms of a voluntary arrangement is related to other recommendations that the Insolvency Sub-Committee is likely to propose regarding voluntary arrangements.

These proposals differ from current law in a few other respects. First of all, the period of the statutory demand has been increased from one to three weeks. In so doing, the Insolvency Sub-Committee adopts the time period used in section 178(a) of the Hong Kong Companies Ordinance (the "Companies Ordinance") that is applicable in compulsory company liquidations, as well as in current English bankruptcy law. One should not object too strongly to a three-week period, given that the Insolvency Sub-Committee is likely to recommend the adoption of a provision along the lines of section 270 of the UK Insolvency Act 1986. Such a provision would enable creditors to petition for a debtor's bankruptcy before the expiry of the three-week period in cases in which there is a serious likelihood that the debtor's assets or the value of their property will be significantly diminished during that period.

A second difference from current law is that the proposals delete the requirement that the statutory demand be based on a judgment. This change in the law will save creditors the unnecessary expense and time that is incurred at present in complying with current law and will enable creditors to petition for bankruptcy earlier than they can at present. To counter arguments that abolishing the judgment debt requirement will abridge a debtor's right to have a fair opportunity to resist a creditor's claim, the Insolvency Sub-Committee will also likely propose that a petitioning creditor who makes a statutory demand that proves to be a false demand should be subject to the sanction of the court as regards costs. This appears to be a sensible way to streamline the bankruptcy petitioning process, yet also protect the right of debtors. A third difference is that the likely proposed language regarding unsatisfied executions will bring the Bankruptcy Ordinance into line with the language used in section 178(b) of the Companies Ordinance. This is also a sensible reform.

The Cork Report notes that:

19 This proposal adopts "deemed to be" language rather than the Harmer Report's concept of premising bankruptcy proceed- ings on "available evidence" of the debtor's inability to pay his or her debts. See the Harmer Report, para 365. 
[ $t$ ]he elimination of the doctrine of the act of bankruptcy . . is not merely a question of modernising and simplifying the grounds upon which a creditor may initiate insolvency proceedings. It represents a fundamental change in the law of bankruptcy with far-reaching consequences. ${ }^{20}$

This change and its consequences should be welcomed. Of course, abolishing the concept of acts of bankruptcy necessitates that other amendments be made to other sections of the Bankruptcy Ordinance. Other recommendations of the Insolvency Sub-Committee will likely propose these changes. For example it is understood that the Insolvency SubCommittee will likely propose that the concept of "relation back" should be abolished and that Topic 2 will likely recommend that appropriate changes be made to the jurisdictional requirements.

\section{Topic 2. Jurisdiction of the court}

\section{Ukely recommendations of the lnsolvency Sub-Committee}

- Provisions along the lines of section 265 of the UK Insolvency Act 1986 should be adopted and the grounds on which jurisdiction can be established should be -

(a) domicile in Hong Kong, or

(b) personal presence in Hong Kong on the day on which the petition is presented, or

(c) being ordinarily resident or having had a place of residence in Hong Kong within three years of the date of presentation of the petition or

(d) having carried on business in Hong Kong (as interpreted by section 265(2) of the UK Insolvency Act 1986) within three years of the date of the presentation of the petition, or

(e) having assets at the date of presentation of the petition or having or being likely to have assets in Hong Kong within 28 days of the date of the presentation of the petition.

A debtor must fulfil certain statutory criteria before the Hong Kong courts have jurisdiction to adjudicate that person a bankrupt. These statutory criteria should ensure that a debtor has sufficient contacts or a geographical connection with Hong Kong to justify his or her bankruptcy in Hong Kong. The current jurisdictional criteria are somewhat confusing

20 The Cork Report, para 530. 
as they provide for jurisdictional bases both at the time of the occurrence of an act of bankruptcy and at the time that (or within a year before the date on which) the bankruptcy petition is filed. Section 3(2) of the Bankruptcy Ordinance provides that "a debtor" -

includes any person, whether a British subject or not, who at the time when any act of bankruptcy was done or suffered by him -

(a) was personally present in Hong Kong; or

(b) ordinarily resided or had a place of residence in Hong Kong; or

(c) was carrying on business in Hong Kong, personally or by means of an agent or manager; or

(d) was a member of a firm or partnership which carried on business in Hong Kong.

Section 6 of the Bankruptcy Ordinance sets out the conditions on which a creditor may petition. Section $6(\mathbf{l})(\mathrm{d})$ provides that a creditor shall not be entitled to present a bankruptcy petition against a debtor unless -

the debtor is domiciled in Hong Kong, or within a year before the date of the presentation of the petition has ordinarily resided, or had a dwellinghouse or place of business, in Hong Kong, or has carried on business in Hong Kong, personally or by means of an agent or manager, or is or within the said period has been a member of a firm or partnership of persons which has carried on business in Hong Kong by means of a partner or partners or an agent or manager.

Sections 3(2) and 6(1)(d) are the Hong Kong counterparts of sections 1(2) and 4(1)(d) of the English Bankruptcy Act 1914. What Williams and Muir Hunter on Bankruptcy states in regard to the English sections is also true of the Hong Kong sections: "[I]t should be noted that section [6(1)(d)] does not come into operation unless the debtor is within section [3(2)]; if the case is within section [3(2)], it must also be brought within this section."21

The Insolvency Sub-Committee is likely to recommend that section 6(1)(d) be replaced by a Hong Kong version of section 265 of the UK Insolvency Act 1986, which would provide as follows:

(1) A bankruptcy petition shall not be presented to the court . . unless the debtor -

(a) is domiciled in Hong Kong,

(b) is personally present in Hong Kong on the day on which the petition is presented, or

21 Williams and Muir Hunter on Bankruptcy, 19th ed, 53 (writing in reference to sections $1(2)$ 
(c) at any time in the period of three years ending with that day --

(i) has been ordinarily resident, or has had a place of residence, in Hong Kong, or

(ii) has carried on business in Hong Kong.

(2) The reference in subsection (1)(c) to an individual carrying on business includes -

(a) the carrying on of business by a firm or partnership of which the individual is a member, and

(b) the carrying on of business by an agent or manager for the individual or for such a firm or partnership.

The Insolvency Sub-Committee is also likely to propose that an additional ground be added - that the debtor has assets at the date of presentation of the petition or will have or is likely to have assets in Hong Kong within 28 days of the date of the presentation of the petition. Lastly, to make the jurisdictional criteria consistent with the abolition of the concept of acts of bankruptcy, the jurisdictional criteria in section $3(2)$ of the Bankruptcy Ordinance should be deleted.

These proposed jurisdictional criteria are much broader than the current criteria - the reference to citizenship is dropped, the period of residency and carrying on of business has been increased from one year to three years, and an assets criterion has been included as a jurisdictional basis. The clearest jurisdictional criteria are domicile, residence, or the carrying on of business in Hong Kong at the time the petition is presented, because these factors demonstrate a clear connection between a debtor and Hong Kong. Although residency and the carrying on of business within three years of the presentation of the petition do not demonstrate as clear a connection, their inclusion is justified by the need to gain jurisdiction over absconding debtors who run up debts in Hong Kong but then flee from Hong Kong with their assets. ${ }^{22}$ By enabling the courts to adjudicate such individuals bankrupt, these criteria enable a bankruptcy trustee to begin a search for assets, and to seek to have the bankruptcy order recognized and enforced abroad.

However, it must be kept in mind that bankruptcy orders issued in the case of absconding debtors who have emigrated and are no longer domiciled in Hong Kong or no longer reside or carry on business in Hong Kong may not always be enforced abroad. Assistance, of course, would be forthcoming from courts in the United Kingdom under section 426 of the UK Insolvency Act 1986; however, in other jurisdictions, it is argu- 
able that recognition and assistance would not be forthcoming as the bankruptcy proceeding in Hong Kong would not be the primary bankruptcy proceeding. The primary proceeding would more likely be in the jurisdiction in which the debtor was domiciled or had his or her primary residence.

The jurisdictional criteria based on personal presence or on the presence of assets may perhaps be criticized as enabling the court to adjudicate the bankruptcy of a person who has only a tenuous connection to Hong Kong, such as someone who just happens to be visiting Hong Kong or someone who merely has investments being held, or funds clearing, in Hong Kong for a short period of time. However, it should be pointed out that under current law the Hong Kong courts have the discretion under section 5 of the Bankruptcy Ordinance to decide whether a receiving order would be appropriate and under section 14 to decide whether to stay pending proceedings. It would be even better if Hong Kong enacted a provision on the order of section 266(3) of the UK Insolvency Act 1986, which gives a court a general power to dismiss a bankruptcy petition or to stay proceedings as it sees fit. ${ }^{23}$ It must also be kept in mind that the inclusion of these criteria will "catch" the following persons - persons who do not satisfy the definition of residency, but who have run up debts in Hong Kong while living here for short periods of time or while visiting Hong Kong on a regular basis; ${ }^{24}$ and persons who have run up debts abroad with Hong Kong creditors, but have property in Hong Kong. Thus, although these two criteria will be used infrequently, they might well prove necessary in enabling the court to have jurisdiction over debtors who have a clear connection with Hong Kong, but do not satisfy the more frequently used jurisdictional requirements.

Although the inclusion of the presence of assets as a jurisdictional basis for bankruptcy is a legitimate addition to current law, there is a problem with the Insolvency Sub-Committee's proposal in so far as it enables jurisdiction to be based on the presence of assets or the likely presence of assets in Hong Kong within 28 days of the date of the presentation of the bankruptcy petition. The origin for this proposal is most likely the case of Re Irish Shipping Ltd, ${ }^{25}$ which involved jurisdiction in the context of winding up. In obiter in that case, Jones J claimed that jurisdiction could be

23 For a discussion of the application of the power of courts to dismiss a bankruptcy petition in the United Kingdom, see Fletcher and Crabb, ibid $45 / 265$, at 45-216; Smart, Cross Border Insolvency
(1991) 11 .

24 See Fletcher and Crabb, supra n 22, 45/ 265 , at $45 \sim 216$.

25 [1985] HKLR 437. 
founded on the presence of assets in Hong Kong on the day the petition was heard. ${ }^{26}$ However, the date for determining jurisdiction should surely be the date the petition is presented. As P Smart states: "Either the court has jurisdiction when the petition is presented or it does not." ${ }^{27}$ It would be rare for a fact situation similar to that of Re Irish Shipping Ltd to arise in the bankruptcy context. But if it did and creditors were worried that assets were going to enter and leave Hong Kong before a petition could be heard, then such creditors should file a bankruptcy petition when the assets arrive in Hong Kong.

An ambiguity that exists in section 265(2)(b) of the UK Insolvency Act 1986 is that the reference to an individual carrying on business includes "the carrying on of business by an agent or manager for the individual" (emphasis added). As P Smart notes, the old UK provision (and current section (6)(d) of the Bankruptcy Ordinance, for that matter) referred to carrying on business "by means of an agent", which would include carrying on business "by" or "through" an agent, ${ }^{28}$ in contrast, the likely proposal includes only the language "by an agent". Thus, rather than recommending the adoption of the UK provision section 265(2)(b) wholesale, the Insolvency Sub-Committee should recommend the retention of the "by means of an agent" language that is currently in section $6(1)$ (d) of the Bankruptcy Ordinance.

Lastly, one important jurisdictional issue that the Insolvency SubCommittee does not appear to have addressed is whether the jurisdictional criteria in the Bankruptcy Ordinance for individuals and the jurisdictional criteria for corporate debtors should be merged into a single jurisdictional provision applicable to both individuals and corporate debtors. This was the recommendation of the Cork Report ${ }^{29}$ (although this reform as not adopted in the UK Insolvency Act 1986), and is the practice in the United States. ${ }^{30}$

\section{Topic 3. Minimum debt}

\section{Likely recommendations of the Insolvency Sub-Committee}

- The amount of the minimum debt where creditors petition for bankruptcy should be raised to $\mathrm{HK} \$ 10,000$.

- The minimum debt amount should be capable of amendment by sub-

26 lbid, at 444.

27 Smart, supran 23 , at 62 n 14.

$28 \mathrm{Ibid}$, at 2829
29 The Cork Report, para 533.

30 See 11 USCA ss 101(41), 109, 301, 303, 304 (West 1992). 
sidiary legislation rather than by amendment of the primary legislation.

- There should be no minimum debt amount on a debtor's own petition for bankruptcy.

Under section 6(1)(a) of the Bankruptcy Ordinance, a creditor is not entitled to present a bankruptcy petition against a debtor unless "the debt owing by the debtor to the petitioning creditor, or if two or more creditors join in the petition, the aggregate amount of debts owing to the several petitioning creditors, amounts to more than HK $\$ 5,000 . "{ }^{31}$ Section 10 of the Bankruptcy Ordinance, which provides for the voluntary filing by the debtor of a petition, does not require a minimum debt amount.

The current debt amount of $\mathrm{HK} \$ 5,000$ was introduced into legislation in 1976, and no adjustments for inflation have been made since that time. According to the Consumer Price Index " $\mathrm{A}$ " calculated by the Census and Statistics Department, HK\$15,900 in 1990 is the equivalent of HK $\$ 5,000$ in 1976. It is understood that the Official Receiver suggested a figure of HK $\$ 10,000$ for the minimum debt after finding that few petitions in Hong Kong are presented for less than that amount anyway. Although increasing the minimum debt amount would affect the right of employees to petition for the bankruptcy of their employer, such employees would be protected by section 16(1)(a) of the Protection of Wages on Insolvency Ordinance, ${ }^{32}$ which enables the Commissioner for Labour to make ex gratia payments from the Protection of Wages on Insolvency Fund to employees who are barred from presenting a bankruptcy petition against their insolvent employers solely because the claim or the aggregate amount of claims does not exceed the amount required by section 6(1)(a) of the Bankruptcy Ordinance. Lastly, a survey by the Insolvency Sub-Committee of the minimum debt amount on a creditor's petition in other jurisdictions demonstrated that the current $\mathrm{HK} \$ 5,000$ amount was substantially lower than the amount required in England and Wales, and Australia, and that the proposed amount of $\mathrm{HK} \$ 10,000$ would be in line with the amounts required in those jurisdictions. ${ }^{33}$

As seen in the discussion of the likely proposed abolition of the concept of acts of bankruptcy, the Insolvency Sub-Committee appears to believe that the underlying rationale for bankruptcy law should generally be debtor's inability to pay. Raising the minimum debt requirement would

31 S 6(1)(a), Bankruptcy Ordinance (Amended, 65 of 1976, s 2).

32 Cap 380, Laws of Hong Kong 1992.

33 In contrast, the Insolvency Sub-Commit- tee noted that the minimum debt amount on a creditor's petition in New Zealand or Singapore is lower than the amount required in Hong Kong. 
be in keeping with this rationale, as it would protect the debtor against petitions based on smaller claims that the debtor might well be able to pay back over time. In addition, if a debtor believed that they could not repay debts that amounted to less than HK $\$ 10,000$, they could always file a voluntary petition. Thus, it is also in keeping with this rationale that there should be no minimum debt amount in voluntary cases.

The likely recommendation that the minimum debt amount should be capable of amendment by subsidiary legislation rather than by amendment of the primary legislation will make it easier for the minimum debt amount to be amended, and thereby easier for inflation to be taken into account. Most likely, the Financial Secretary, on the recommendation of the Official Receiver, will be allowed to make adjustments to the minimum debt amount.

\section{Topic 4. Statutory deposit (petitioner's deposit)}

\section{Ulkely recommendations of the Insolvency Sub-committeo}

- The statutory deposit should be reduced to HK $\$ 5,000$.

- The amount of the statutory deposit should be capable of adjustment from time to time and this should be done by subsidiary legislation rather than by amendment of the primary legislation.

Under Bankruptcy Rule 52(1) ${ }^{34}$ upon the presentation of a bankruptcy petition the petitioner must deposit $\mathrm{HK} \$ 10,000$ with the Official Receiver to cover the Official Receiver's fees and expenses. (Until 1985, the amount was $\operatorname{HK} \$ 1,000$.) Further under Bankruptcy Rule 52(1), the court may direct the petitioner to deposit additional sums to cover additional fees and expenses to be incurred by the Official Receiver.

It is understood that the Insolvency Sub-Committee pointed out that the Hong Kong Government increased the amount of the statutory deposit in 1985 by $1000 \%$ as part of a deliberate policy to restrict the number of bankruptcy petitions filed, and that this attempt, in fact, was at least partly successful. It is also understood that the Insolvency SubCommittee noted that the statutory deposit in England and Wales is substantially lower than the statutory deposit in Hong Kong (approximately HK $\$ 3,120$ for a creditor's deposit and HK $\$ 1,560$ for a debtor's deposit). ${ }^{35}$

34 Cap 6, Laws of Hong Kong 1992.

35 The Insolvency Sub-Committee also noted that the amounts of the statutory de- posit in New Zealand and Australia are more in line with those in England and Wales. 
The likely proposal of the Insolvency Sub-Committee will be to reject the restrictive policy of the Hong Kong Government as incorporated in the 1985 amendment in favour of one that enables as many people as possible, and especially small businesses, to be able to afford the statutory deposit and to commence bankruptcy proceedings where necessary. It is understood that the majority of the Insolvency Sub-Committee believes that the statutory deposit should be a fraction of the minimum debt, and, therefore, that the statutory deposit should be reduced to HK $\$ 5,000$ for both creditors' and debtors' petitions.

It is understood that the minority of the Insolvency Sub-Committee believes that the present level of the statutory deposit for a creditor's petition is satisfactory and that it should in the future be maintained at a level sufficient to cover the Official Receiver's costs and expenses in an average case. (It is also understood that the Official Receiver proposed that the statutory demand for debtor's petitions should be reduced or abolished.) It is further understood that a minority of Insolvency SubCommittee members fear that reducing the amount of the statutory deposit for creditors' petitions could lead to an increase in spite or nuisance petitions.

Given the current bankruptcy regime, in which the Official Receiver usually serves as the trustee in bankruptcy cases, the majority proposal strikes a reasonable compromise - a statutory deposit of $\mathrm{HK} \$ 5,000$ is intended to balance the policy of making bankruptcy a remedy available to a larger group of creditors against the need of ensuring that the Official Receiver can cover the basic expenses and costs that are likely to arise. It is understood that the HK $\$ 5,000$ amount was chosen because the majority of the Insolvency Sub-Committee believes that this amount is large enough to fund the Official Receiver's basic expenses and costs in a typical case until assets being realized can be applied to cover additional administration expenses. In those cases in which further deposits are necessary to cover the additional fees and costs incurred by the Official Receiver (such as for legal proceedings or investigations), the majority will likely recommend that the Official Receiver contact creditors for further financial contributions earlier than he does at present; and in cases in which such further financial support is not provided by creditors, that the Official Receiver be entitled to scale down his investigations and use the summary procedures under section 112A of the Bankruptcy Ordinance.

The issue about the proper amount of the statutory deposit is related to a larger, and more fundamental issue - that of whether the Official Receiver should play such a large role in bankruptcy proceedings in 
Hong Kong. In a sense, the Hong Kong Government presently subsidizes part of the collective debt collection effort of creditors (and the statutory debt enables the Government to recoup some of these costs) and the creditors must supply the rest if there are insufficient assets in the estate. One could imagine a system in which a private interim trustee was appointed (perhaps by the Official Receiver) and continued to serve as trustee unless the creditors elected their own trustee. ${ }^{36}$ Such interim trustees and trustees would recover payment of their costs and fees from the bankrupt's estate. Rather than looking to recoup costs on a case by case basis by benefiting from a large statutory deposit, interim trustees/ trustees could look to the long-term for reimbursement and profit - that is, after serving as an interim trustee/trustee in a few no-, or low asset cases, an interim trustee would be appointed to a profitable case. The reimbursement of costs and fees earned in that case would more than offset the possible losses incurred in the other cases. Under such a system, the statutory deposit amount could be set low enough to cover basic administrative expenses, and creditors would not be asked (as they may be at present under Bankruptcy Rule 52(1)) to deposit additional sums to cover additional administrative expenses. Perhaps this proposal could be of some relevance in the future given that it is understood that the Official Receiver is committed to a system of "licensed" insolvency practitioners and to the privatization of the administration of estates work presently done by his office, with the Official Receiver serving in a supervisory capacity.

The likely recommendation that the statutory deposit should be capable of amendment by subsidiary legislation rather than by amendment of the primary legislation, as in the case of the minimum debt, will make it easier for the amount to be amended and for inflation to be taken into account.

\section{Topic 8. Meetings of creditors}

\section{Likely recommendations of the Insolvency Sub-Committee}

- The Official Receiver should have a discretion whether to hold a first meeting of creditors, probably along the lines of sections 293 and 294 of the UK Insolvency Act 1986. 
- The quorum should be reduced to one creditor present or represented at the meeting.

- The provisions about creditors' meetings should be consolidated within the Bankruptcy Ordinance and the Meetings of Creditors Rules.

- The Meetings of Creditors Rules should be properly side margined.

Under the current bankruptcy law regime, the primary issue to be resolved at the first meeting of creditors is whether the debtor is to be adjudicated bankrupt, or whether a proposal for a composition or scheme of arrangement should be accepted. ${ }^{37}$ It is understood that the Insolvency Sub-Committee will be recommending that the receiving order and the adjudication order be consolidated into a single bankruptcy order and that this likely proposal, in the Insolvency Sub-Committee's view, would remove a primary reason to hold the first meeting at all. It is also understood that in the Insolvency Sub-Committee's view, the other functions of the first meeting of creditors - considering a proposal by the bankrupt, appointing a committee of inspection, and determining the mode of dealing with the bankrupt's property - are all matters that the debtor or the creditors can initiate. The Insolvency Sub-Committee will therefore likely propose that the Official Receiver should have a discretion whether to hold a first meeting of creditors. These proposals will likely be along the lines of sections 293 and 294 of the UK Insolvency Act 1986.

Section 293 of the UK Insolvency Act 1986 requires the Official Receiver (in cases not involving a summary administration of the bankrupt's assets (in Hong Kong, section 112A of the Bankruptcy Ordinance sets out similar procedures for the summary administration of small bankruptcies) to decide as soon as practicable within 12 weeks from the date of the bankruptcy order, whether or not to call a first meeting of creditors for the purpose of appointing a trustee of the bankrupt's estate. If the Official Receiver does not call such a meeting, he shall serve as the trustee of the debtor's estate, and must give notice of his decision to the court and to all known creditors. Section 294 of the UK Insolvency Act 1986, in turn, allows creditors to request the Official Receiver to hold a meeting for the purpose of selecting a trustee if a certificate for the summary administration of the estate is not in force, and the Official

37 S17(1), Bankruptcy Ordinance. Other matters often decided at the first meeting include selecting a trustee, appointing a committee of inspection, and resolving issues as to the mode of dealing with the debtor's property. Ss 23, 24, 17(1), Bankruptcy Ordinance. 
Receiver must summon such a meeting if the request appears to be made with the concurrence of not less than one-quarter, in value, of the bankrupt's creditors. It is understood that the Official Receiver stressed to the Insolvency Sub-Committee that such changes, if adopted, would enable the Official Receiver to avoid holding unnecessary meetings. Similarly, another likely proposal to make the meetings procedure more efficient is that the quorum for meetings be reduced to one creditor present or represented at a meeting. ${ }^{38}$ It is understood that in the Insolvency SubCommittee's view, this reform will help ensure that if a meeting is called, a sufficient quorum will attend.

These likely proposals to streamline the bankruptcy procedures in appropriate cases, in effect, put the burden on creditors to initiate meetings. The Insolvency Sub-Committee appears to have been influenced by reports that in many cases the present quorum requirement has not been met, and as noted above, a belief that the Official Receiver should be able to cancel unnecessary meetings. That may well be true, but these changes also diminish the role to be played by creditors in bankruptcy proceedings. The onus will now be on the creditors to contact each other and to seek support if they wish to request the Official Receiver to hold the first meeting, and it is possible that the views of minority creditors (who cannot meet the one-quarter in value requirement) will be ignored. ${ }^{39}$ These changes might well be tailored to the situation in Hong Kong, but the Insolvency Sub-Committee should realize that its proposal to allow the Official Receiver to diminish the participation of creditors might in some cases have an unintended effect on the likelihood of Hong Kong bankruptcy orders being recognized and enforced abroad.

For instance, in a recent US section 304 case a court refused to recognize Australian compulsory liquidation proceedings for failing to provide US creditors with similar substantive and procedural protection as is provided by US bankruptcy law. ${ }^{40}$ In this case, which I believe was wrongly decided, the court based its decision primarily on the facts that (i) creditors had not been notified prior to the ratification of an important agreement entered into by the liquidator and one of the debtor's creditors, and (ii) there was not a comparable remedy of equitable subordina-

38 The current requirement is for three creditors, or all the creditors if their number does not exceed three, to be present or represented at a meeting. $R 24$, Meetings of Creditors Rules, Cap 6, Laws of Hong Kong 1992. The proposal for the reduced quorum tracks $r$ 12.4A of the UK Insol- vency Rules 1986, enacted in 1987.

39 It is understood that this is the view of a minority of the Insolvency SubCommittee.

40 Interpool Ldd $v$ Certain Freights of $M / V$ Venture Star 102 BR 373 (DNJ 1988), appeal dismissed, 878 F2d 111 (3d Сiг 1989) ("Interpool"). 
tion under Australian law as exists under US law. However, for our purposes, it should be noted that the court also considered whether the trustee and creditors had held a series of meetings regarding the liquidation of the assets in the debtor's estate. ${ }^{41}$ Thus, a US court might possibly fail to recognize a bankruptcy order in a case in which the attempt by minority creditors to hold a first meeting has been ignored by the Official Receiver. The Official Receiver, in such a case, could of course point to other fundamentally fair procedures existing under $\mathrm{HK}$ law to protect creditors. However, it would certainly be better for the Official Receiver to hold the first meeting of creditors in cases in which it appears likely that foreign assistance will be sought.

If the sub-committee's proposals are to be adopted, I believe that 12 weeks is too long a period for the Official Receiver to have for deciding whether or not to hold the first meeting. I would propose that the Official Receiver must decide within four weeks of receiving the debtor's statement of affairs - thus, the decision would have to be made within four weeks of the filing of the petition in cases commenced by the debtor herself, and within seven weeks, at the longest, in cases commenced by creditors. (See the discussion of statements of affairs in Topic 10 below.) This shorter time period would still ensure that the Official Receiver has enough time to decide whether or not to hold the first meeting of creditors, but would be fairer to creditors and enable them to decide earlier if they should initiate a meeting.

Lastly, the Insolvency Sub-Committee will likely be proposing that the new provisions concerning creditors' meetings should be consolidated within the Bankruptcy Ordinance and the Meetings of Creditors Rules and that the Meetings of Creditors Rules should be properly side margined. It is understood that the Insolvency Sub-Committee decided against adopting the UK Insolvency Rules 1986 on meetings of creditors after finding that the UK rules are too detailed for the needs of Hong Kong and that the Hong Kong rules are adequate when considered with the sub-committee's recommendations.

41 Ibid, 102 BR at 378-80. I discuss and criticize the approach of the Interpool court in my article, "Recognition of Foreign Bankruptcies: An Analysis and Critique of the Inconsistent Approaches of United States Courts" (1992) 66 American Bankruptcy Law Journal 135, 200-12. See also Glosband and Katucki, "Current Developments in International Insolvency Law and Prac- tice" (1990) 45 Business Lawyer 2273, 2277-78; Glosband and Katucki, "US Court Declines Recognition of Australian Insolvency Proceedings" (1990) 2 Interna-

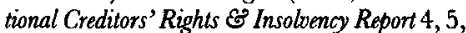
17; Hughes, "An Australian Perspective on Interpool", (1990) 2 Intemational Insolvency \&' Creditors' Rights Report 32, 33-34. 


\section{Topic 10. Statement of affairs}

\section{Ukely recommendations of the insolvency Sub-Committee}

- The time for submission of the statement of affairs should be increased to 21 days from the date of the bankruptcy order in the case of an order made on a creditor's petition.

- The statement of affairs should be submitted at the same time as the petition where a debtor petitions for his own bankruptcy.

- The Official Receiver should have the discretion to dispense with the statement of affairs where he considers it unnecessary, without the need to apply for an order of the court.

- The Official Receiver should have the power to extend the time for submission of the statement of affairs without having to file a certificate in court.

- The circumstances under which a debtor may be in contempt of court under section 18(3) of the Bankruptcy Ordinance should be more clearly set out.

- The prescribed form of the statement of affairs should be available in Chinese, simplified, and printed on standard size paper.

It is understood that the first four of these proposals originated with the Official Receiver and that the Insolvency Sub-Committee views these proposals as minor and practical. They might well be, but they are also very important. These proposals, if adopted, will abolish inefficient procedures that the Official Receiver and debtors must currently follow.

Under current section 18(2)(b) of the Bankruptcy Ordinance, a debtor must submit the statement of affairs within seven days from the date of the receiving order in cases commenced by a creditor. It is understood that the Official Receiver finds this seven-day time limit to be "unrealistic" and therefore has proposed that it be lengthened to 21 days, and that the Insolvency Sub-Committee supports this proposal as a more practical and realistic time limit. Under current section 18(2)(a) of the Bankruptcy Ordinance, the debtor must submit the statement of affairs within three days from the date of the receiving order in cases commenced by the debtor himself. ${ }^{42}$ It is understood that the Official Receiver finds this time delay to be necessary and has proposed that the debtor file the statement of affairs with the petition when the debtor peti-

42 Under section 18(2) of the Bankruptcy Ordinance, the court may for special rea- sons extend the time for filing the statement of affairs. 
tions for his own bankruptcy. It is understood that the Insolvency SubCommittee also supports this proposal - in its view, since the debtor is aware of his financial position at the time he files the petition, he should share this information with the Official Receiver at that time. These likely proposals recommending changes in the time limits for filing statements of affairs parallel the reforms enacted in section 272(2) (regarding a debtor's petition) and section 288(1) (regarding orders made otherwise than on a debtor's petition) of the UK Insolvency Act 1986.

The other likely proposals that originated with the Official Receiver attempt to streamline the current procedures regarding statements of affairs. The first will give the Official Receiver discretion to dispense with the statement of affairs in cases where he considers it unnecessary, without having to apply for an order of the court as is presently required under Bankruptcy Rule 81A. The second will give the Official Receiver the power to extend the time for submission of the statement of affairs without having to file a certificate in court, as is currently required under Bankruptcy Rule 82. It is understood that the Insolvency SubCommittee supports both of these recommendations by the Official Receiver - that in the sub-committee's view, adoption of the former would not prejudice any party, and adoption of the latter would parallel section 190(3) of the Companies Ordinance, which applies in the winding up of a company.

The Insolvency Sub-Committee will also likely propose to clarify section 18(3) of the Bankruptcy Ordinance through amendment along the lines of section 288(4) of the UK Insolvency Act 1986. Section 288(4) provides as follows:

A bankrupt who-

(a) without reasonable excuse fails to comply with the obligation imposed by this section [to submit a statement of affairs on time], or

(b) without reasonable excuse submits a statement of affairs that does not comply with the prescribed requirements,

is guilty of a contempt of court and liable to be punished accordingly (in addition to any other punishment to which he may be subject).

In contrast, section 18(3) of the Bankruptcy Ordinance currently provides that a debtor commits a contempt of court if he "fails without reasonable excuse to comply with the requirements of this section." As the Insolvency Sub-Committee is understood to have noted, adoption of the language from section 288(4) of the UK Insolvency Act 1986 would clarify the reasons for a debtor being found guilty of a contempt of court 
and would make explicit that the debtor is required to complete a statement of affairs as prescribed in section 18(1) of the Bankruptcy Ordinance.

The final likely proposals regarding the statement of affairs - to make the statement of affairs form available in Chinese (or perhaps to have a bilingual form), to simplify and modernize the form, and to replace the present unwieldy form with a form entirely printed on a standard size paper - will make the form easier to use and should all be welcomed. Making the form understandable to debtors, whose primary, and often only, language is Chinese is especially important.

\section{Topic 15. Proof of debt}

\section{Likely recommendations of the Insolvency Sub-Committee}

- Proof of debts should be made in writing and need not be sworn unless the trustee considers that it is necessary for the proof to be verified by affidavit.

- For the purposes of valuation for dividends, foreign currency debts should be converted into Hong Kong dollars as at the date of the making of the bankruptcy order.

- If a trustee, on taking expert advice, considers that it would be beneficial to the estate to delay the conversion of foreign currency to Hong Kong dollars it should be in his discretion to do so but only with the approval of the creditors' committee, or the court in the absence of a creditors' committee.

- Provided that a trustee has foreign currency assets and is satisfied that claims in that currency will be admitted for the purposes of paying a dividend, a trustee should have a discretion, with the approval of the creditors' committee or the court, if appropriate, to retain such part of the foreign currency on deposit as is considered appropriate to pay dividends in that currency.

- Proofs of debt for tort claims should be admitted to proof subject to a trustee either making an estimate of the value of a debt or liability or referring the claim to the court for valuation. There should be a right of appeal from an estimate made by a trustee.

- Fines and penalties should not be admissible in bankruptcy nor should they be released by the bankrupt's discharge.

The first likely proposal in Topic 15 is one that will simplify the procedure for submitting proofs of debt and will save creditors unnecessary 
time and expense. At present, rule 2 of the Proof of Debts Rules ${ }^{43}$ provides that a debt shall be verified by affidavit. This requires creditors to invest additional time and expense in the filing of their proofs, often including a visit to a City or District Office to have documents sworn before government officials. It is understood that the Insolvency Sub-Committee noted that now that many of these offices have been closed, creditors have had to invest even more time in travelling to other offices. This likely proposal to allow all proofs to be in writing and unsworn, unless the trustee thinks that it is necessary for the proof to be verified by affidavit, is a sensible administrative reform. ${ }^{44}$

The Insolvency Sub-Committee is likely to make a few proposals regarding foreign currency debts. The sub-committee's first likely proposal, for the purposes of the valuation for dividends is to convert foreign currency debts into Hong Kong dollars under a rate of exchange existing at the date of the making of the bankruptcy order. This is an important recommendation, for at present there is no such provision in the Bankruptcy Ordinance although the practice in Hong Kong has been to convert foreign currency debts as at the date of the receiving order. It is understood that the Insolvency Sub-Committee realizes the need to choose the same date for all creditors.

Given that the Insolvency Sub-Committee will likely propose to replace the two-step receiving order/adjudication order procedure with a one-step bankruptcy order procedure, the question arises as to which date to choose for selecting the conversion rate to be used for converting foreign currency debts. It is understood that the Official Receiver proposed that the applicable date should be either the date of the presentation of the petition or the date of the making of the bankruptcy order, and that the Insolvency Sub-Committee supports the latter proposal. Converting foreign currency debts as of the date of the bankruptcy order also happens to be the rule in England, ${ }^{45}$ although that rule must be viewed in the context of section 278 of the UK Insolvency Act 1986, which states that bankruptcy commences at the date of the bankruptcy order. There is no equivalent section under current Hong Kong law, and even if there were, that section should not be relied on for the purpose of choosing the date on which to convert foreign currency debts - for such a purpose, the relevant date should not be the date that the debtor's bank-

43 Cap 6, Laws of Hong Kong 1992.

44 This change was also enacted in the United Kingdom. See rules 6.96 and 6.99 ,
UK Insolvency Rules 1986.

45 Rule 6.111(1), UK Insolvency Rules 1986. 
ruptcy commences (i.e., the date of the bankruptcy order), but rather should be the date on which the bankruptcy process commences and the non-bankruptcy rights of creditors are affected, which is the date that the bankruptcy petition is presented. After all, it is on the date that the bankruptcy petition is presented that the court has the power to stay the actions of creditors against the debtor or the debtor's property, ${ }^{46}$ it is therefore this date as of which the court should both determine the amount of a creditor's claim and convert any foreign currency debts. ${ }^{47}$ However, putting aside any disagreement about which date is preferable for converting foreign currency debts for the purposes of valuation of dividends, the more important point to bear in mind is that the Insolvency Sub-Committee will likely (and rightly) pick one date for converting the foreign currency claims of all creditors.

Another likely proposal regarding foreign currency debts involves setting the date for physically converting foreign currency into Hong Kong dollars. (This date should not be confused with the date chosen for setting the exchange rate for the conversion of foreign currency claims, which is discussed in the preceding two paragraphs.) It is understood that the Insolvency Sub-Committee is concerned that large amounts of money could be at stake in some insolvencies and believes that the trustee and creditors should be given some flexibility in dealing with assets in foreign currencies. The sub-committee will, therefore, likely propose that if a trustee, on taking expert advice, considers that it would be beneficial to the estate to delay the conversion of foreign currency to Hong Kong dollars it should be in his discretion to do so but only with the approval of the creditors' committee, or the court in the absence of a creditors' committee. This is an important proposal that addresses a very practical problem that can adversely affect the size of the debtor's estate. As the Insolvency Sub-Committee is understood to have noted, although it is not the function of the trustee to engage in foreign currency speculation, large benefits can accrue to an estate (and thereby to creditors generally) if a trustee takes advantage of beneficial exchange rates.

The last likely proposal regarding foreign currency involves the situation in which the trustee holds assets in a foreign currency and also knows that foreign currency claims in that currency will be admitted in the Hong Kong bankruptcy for the purposes of paying a dividend. The Insolvency Sub-Committee is likely to propose that in such a case the

46 S 14(1), Bankruptcy Ordinance.

47 Under current law, the amounts of claims are determined as at the date of the receiving order. S 34(3), Bankruptcy Ordinance. 
trustee should have a discretion, with the approval of the creditors' committee or the court, if appropriate, to retain such part of the foreign currency on deposit as is considered appropriate to pay dividends in that currency. It is understood that the goal of this likely proposal, as of the previous one regarding the physical conversion of foreign currency assets, is to give the trustee flexibility in handling foreign currencies while ensuring that she be properly supervised. It appears that these two proposals were generated by the Insolvency Sub-Committee itself, for it is understood that the sub-committee noted that it was not aware of the enactment of such provisions elsewhere.

A further likely proposal is to allow proofs of debts for unliquidated tort claims to be admitted in bankruptcy. Such a change would be an important improvement to Hong Kong bankruptcy law and would abolish the outdated distinction currently existing in section 34(1) of the Bankruptcy Ordinance between unliquidated contract claims (which are provable) and unliquidated tort claims (which are not provable). It is understood that the Insolvency Sub-Committee relied on the following passage from the Cork Report to explain why unliquidated tort claims should be admitted:

It is a basic principle of the law of insolvency that every debt or liability capable of being expressed in money terms should be eligible for proof in the insolvency proceedings, so that the insolvency administration should deal comprehensively with, and in one way or another discharge, all such debts and liabilities. ${ }^{48}$

Of course, if unliquidated tort claims are to be admitted, the difficult issue arises of how to value them if they have not been liquidated by agreement or by judgment before they come to be proved. It is understood that in addressing these issues of provability and valuation the Insolvency Sub-Committee discussed the recommendations made by the Harmer Report and the Cork Report, as well as reviewing the law of the United Kingdom, New Zealand, Ireland, Australia and Singapore. It is also understood that the Insolvency Sub-Committee will likely propose the following procedure for the valuation of tort claims:

The trustee should either make an estimate of the value of a debt or liability or refer the claim to the court for valuation. There should be a right of appeal from an estimate made by a trustee. 
I would like to propose that rather than making this proposal, the Insolvency Sub-Committee should consider making a recommendation along the following lines. My proposal is for the valuation of all claims that have not been liquidated by agreement or by judgment before they come to be proved and incorporates some aspects of the Harmer Report's proposal ${ }^{49}$ and some aspects of the procedure presently available under section 502(b) and (c) of the US Bankruptcy Code: $:^{50}$

(1) The trustee may make an estimate of the value of a debt or liability.

(2) If the creditor accepts the trustee's valuation, then the creditor shall be bound by such valuation.

(3) If the creditor objects to the trustee's valuation, or if the trustee has not made a valuation, the creditor may appeal to, or petition, as the case may be, the court to -

(a) determine the merits of the debt or liability in a streamlined trial and determine the value of the debt or liability, in which case the creditor shall be bound by the court's valuation, or

(b) (i) itself estimate the value of the debt or

(ii) specify a mode of estimating the value of the debt, in which case the creditor may appeal to the court from a value estimated in the specified manner.

(4) If under section (3)(b) above -

(i) the court itself estimates the value of the debt,

(ii) the value of the debt is estimated in the mode specified by the court and the creditor does not appeal, or

49 Paragraph 797 of the Harmer Report provides as follows:

The Commission recommends a procedure for quantification in both individual and corporate insolvency where the amount of claims is not certain. The procedure is based on the Bankruptcy Act s 82(3)-(7) but with the following differences.

- Whereas the Bankruptcy Act requires the trustee to make an estimate of the value of a debt or liability, the Commission recommends that the trustee or liquidator either make an estimate or refer the claim to the court for valuation. The right of appeal from an estimate made by the trustee or liquidator would then be treated as if that person had referred the claim to the court.

- The Commission recommends that the court have a power to specify a mode of determining the value rather than being necessarily required to determine the value itself. It would still be open to appeal to the court from a valuation determined in the specified manner.
50 Section 502 of the US Bankruptcy Code provides, in part, as follows:

(a) A claim or interest, proof of which is filed under section 501 of this title, is deemed allowed, unless a party in interest ... objects.

(b) Except as provided in subsections $(e)(2),(f),(g),(h)$ and (i) of this section, if such objection to a claim is made, the court, after notice and a hearing, shall determine the amount of such claim in lawful currency of the United States as of the date of the filing of the petition, and shall allow such claim in such amount . . . (c) There shall be estimated for purpose of allowance under this section-

(1) any contingent of unliquidated claim, the fixing or liquidation of which, as the case may be, would unduly delay the administration of the case; or

(2) Any right to payment arising from a right to an equitable remedy for breach of performance.

11 USCA s 502(a), (b), (c) (West 1992). 
(iii) the court estimates the value of the debt on appeal from a value estimated in the mode specified by the court,

the creditor shall be bound by such valuation unless the court grants the creditor permission to seek judgment of the debt or liability outside bankruptcy, in which case the creditor may reappear in the bankruptcy once he receives judgment for a different amount and may seek adoption of the judgment amount. ${ }^{51}$

Like the Insolvency Sub-Committee's likely proposal (and the Harmer Report's proposal, upon which it appears to be based), my proposal allows the trustee to make the initial estimate of the value of a debt or liability, thereby avoiding the need for court involvement. However, unlike the sub-committee's proposal, my proposal allows the creditor to appeal to, or to petition, the court to have the value of his claim determined in a streamlined trial, estimated by the court, or estimated in a mode specified by the court. Under my proposal, a creditor should choose to have his claim estimated under section (3)(b)(i) or (ii) if he wants to continue seeking judgment of the claim outside bankruptcy, but the court has the discretion to decide whether or not to allow the creditor to pursue such actions outside bankruptcy. In making this decision, the court should take into account the amount of assets in the bankrupt's estate, the extent to which those assets would be dissipated if litigation were allowed to continue, and the likelihood of a judgment being rendered in a timely fashion.

There might be some reluctance to allowing the court that is handling the bankruptcy to determine the merits of the creditor's debt or liability in a streamlined trial under section (3)(a) of my proposal, as this would involve the adjudication of non-bankruptcy issues. However, the judges handling the bankruptcies would be qualified to resolve the nonbankruptcy issues. ${ }^{52}$ Also, allowing the bankruptcy judges to run streamlined trials (as well as to estimate the value of debts and liabilities, for that matter) would be an efficient solution - a "rough justice" approach to the valuation of debts and liabilities is justified in bankruptcy cases as it is usually not worth the parties' time and expense to have a full trial to determine accurately the value of a debt or liability, given that creditors do

51 Also, current s 24(5) of the Bankruptcy Ordinance should be applicable to the procedure set forth above - any person aggrieved by any estimate made by the trustee should be allowed to appeal to the court.

52 A minor amendment might be necessary to give the judge handling the bankruptcy case jurisdiction to determine merits of monetary claims where the amount claimed is not more than HK\$15,000. These matters, at present, are handled by the Small Claims Tribunal. See s 5 and Schedule, Small Claims Tribunal Ordinance, cap 338, Laws of Hong Kong 1992. 
not receive any distribution at all in some cases, and rarely receive more than $\$ .10$ to $\$ .15$ on the dollar in most asset cases.

It is understood that the final recommendation in Topic 15 will likely be to propose that no fine or penalty imposed by any court should be admissible to proof or be released by a bankrupt's discharge. This was also the recommendation of the Cork Report. ${ }^{53}$ which in turn was incorporated into the UK Insolvency Act $1986 .{ }^{54}$ This recommendation would change the current practice in Hong Kong, for as it is understood that the Insolvency Sub-Committee noted, although the Bankruptcy Ordinance at present does not provide that fines and penalties are provable, the practice is that they are. Enacting this change in law would strengthen the policy that the discharge should only be applicable to claims of the "honest but unfortunate debtor", ${ }^{55}$ and not to penalties or fines that have been incurred by the debtor as punishment for his wrongful behaviour.

\section{Conclusion}

While it is difficult to make overall comments about the likely forthcoming legislation based on a review of these seven topics alone, a few trends do appear to be emerging. First of all, the likely proposals to abolish the concept of acts of bankruptcy and to raise the minimum debt on which to base a creditor's petition from $\mathrm{HK} \$ 5,000$ to $\mathrm{HK} \$ 10,000$, will change the concept of bankruptcy, in that it will be based more of a debtor's financial difficulties than on any "wrongful acts" committed by a debtor against creditors.

Secondly, the Insolvency Sub-Committee appears to be trying to modernize bankruptcy law by abolishing outdated notions, such as the concept of acts of bankruptcy and the prohibition against allowing creditors to submit proofs of debts for unliquidated tort claims.

Thirdly, consistent with this attempt to modernize the law, the Insolvency Sub-Committee will likely propose a number of reforms to streamline the bankruptcy procedures. These include the following: abolishing the requirement that creditors base a statutory demand on a judgment; allowing the Official Receiver on his own to dispense with the statement of affairs when he considers it unnecessary, as well as to extend the time for the submission of the statement of affairs; simplifying the statement of

53 The Cork Report, para 1330.

54 Rule 12.3(2) UK Insolvency Rules 1986; s $28 \mathrm{I}$ (4) UK Insolvency Act 1986.
55 Local Loan Co $v$ Hunt, 292 US 234, 244 (1933), quoted in Baird \& Jackson, supra n 14 , at 810 . 
affairs form and making it available in Chinese; making the deadlines for filing statements of affairs more realistic; and allowing proofs of debt to be unsworn.

Fourthly, it appears that the Official Receiver will continue to play a major role in bankruptcies, given that some of the likely proposals increase the control that the Official Receiver will be able to exert on the bankruptcy process. Most importantly, the Official Receiver will likely be given a discretion whether to hold a first meeting of creditors. In addition, as previously noted, the Official Receiver will likely be given more control over the submission of the statement of affairs.

Fifthly, tied to the role of the Official Receiver (or the role of the trustee), is the role played by creditors. Many of the likely proposals to streamline bankruptcy procedures would not change the current balance of power between the Official Receiver and the creditors. However, the likely changes involved in allowing the Official Receiver to decide whether to cancel the first meeting of creditors will increase the role played by the Official Receiver in the bankruptcy process at the expense of the role of the creditors. In contrast, other likely proposals, such as those contemplating the need for creditors' committees to approve the actions of the trustee regarding foreign currency claims, would lead to an increased role for creditors. This is one area where it is especially important to await the Insolvency Sub-Committee's full recommendations before drawing any conclusions.

Lastly, although most of the likely amendments to the bankruptcy law are based on the UK Insolvency Act 1986, the Insolvency SubCommittee has attempted to consider Hong Kong conditions. At times these local factors justify tailoring the English provisions to meet the needs of Hong Kong. For example, although the Insolvency SubCommittee will likely recommend that the UK provisions setting forth the grounds of a creditor's petition should be adopted, the subcommittee will also likely recommend that an additional ground be added enabling a creditor to petition for bankruptcy in cases where a debtor absconds from Hong Kong. Similarly, an additional jurisdictional basis involving the presence of assets in Hong Kong will likely be added to the other bases that track UK law, and although provisions along the lines of UK law will likely be proposed regarding the first meeting of creditors, it is understood that the Insolvency Sub-Committee found the UK rules regarding the meetings of creditors to be inappropriate for Hong Kong. It should be kept in mind, however, that in some instances the local Hong Kong factors offer strong support for adopting UK provisions. A case in point is that the need to gain jurisdiction over 
absconding debtors justifies adoption of the broader UK jurisdictional bases. In other instances local problems require local solutions. Thus, the Insolvency Sub-Committee will likely recommend that the statement of affairs form should be made available in Chinese. Such a proposal would finally acknowledge that although English is the primary language of the courts, it is not the primary language of the majority of debtors in Hong Kong.

In its first interim report the Insolvency Sub-Committee will propose many more recommendations in addition to the likely ones discussed here, and after the Insolvency Sub-Committee makes its final recommendations to the Law Reform Commission we will have a much better sense of the full scope of bankruptcy reforms that are being contemplated and of whether any "radical" proposals will emerge. Further comment should wait until then. 